\title{
Identifying 'plantscapes' at the Classic Maya village of Joya de Cerén, El Salvador
}

\author{
Alan Farahani ${ }^{1, *}$, Katherine L. Chiou ${ }^{2}$, Anna Harkey ${ }^{3}$, \\ Christine A. Hastorf ${ }^{2}$, David L. Lentz ${ }^{4} \&$ Payson Sheets ${ }^{5}$
}

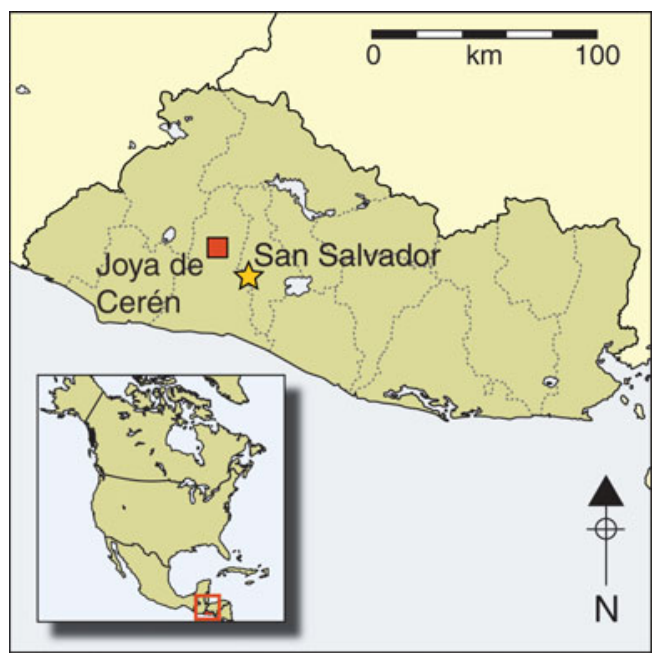

The Classic Maya village of Joya de Cerén is extraordinary in that it was preserved by volcanic ash following the Loma Caldera volcanic eruption. The excellent preservation conditions offer a unique opportunity to understand plants in their primary use contexts, and to examine geospatial relationships between plants — both living and curated —in gardens, fields and households. The geospatial analysis of 'plantscapes' at Cerén presented here provides a template for interpreting botanical resource use and management at other contemporaneous Maya sites, and can contribute to a broader understanding of the use of space, plants and agriculture in the past.

Keywords: El Salvador, Joya de Cerén, Maya, Classic period, GIS, plantscapes, archaeobotany, household archaeology

\section{Introduction}

In the seventh century $\mathrm{AD}$, Joya de Cerén, a Classic Maya-period village located in present-day El Salvador, was entombed in ash following the eruption of a nearby volcano.

1 Cotsen Institute of Archaeology, University of California, Los Angeles, 308 Charles E Young Drive N, Los Angeles, CA 90095, USA

2 Department of Anthropology, University of California, Berkeley, 232 Kroeber Hall, Berkeley, CA 94720-3710, $U S A$

3 Department of Sociology and Anthropology, Wofford College, 429 North Church Street, Spartanburg, SC 293033663, USA

4 Department of Biological Sciences, University of Cincinnati, 2600 Clifton Avenue, Cincinnati, OH 45221-0006, $U S A$

5 Department of Anthropology, University of Colorado Boulder, 1350 Pleasant Street, Boulder, CO 80309-0233, USA

* Author for correspondence (Email: alanfarahani@ucla.edu) 


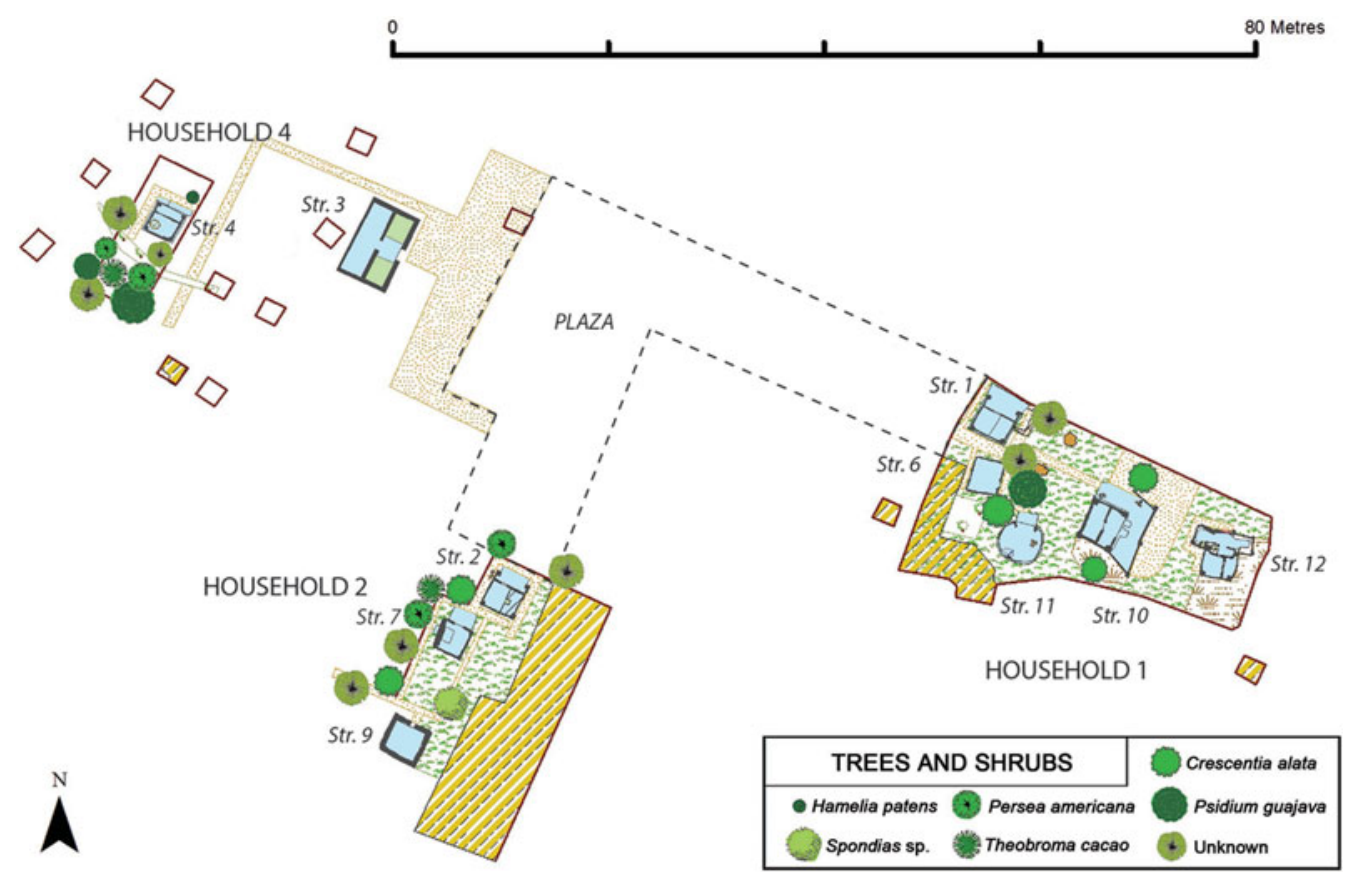

Figure 1. A GIS rendering of all four households at Joya de Cerén, with trees and shrubs identified in the legend.

Although the village was evacuated, the inhabitants, in their haste to escape, left behind nearly all of the materials related to their daily lives. In addition, their fields and kitchen gardens, along with the trees that grew outside their homes, were preserved. These rare preservation conditions have thus far provided extraordinary insight into the daily activities and arrangement of a Maya-period village (Sheets \& Woodward 2002; Sheets et al. 2011, 2012). This article presents recent research on the spatialisation of the wild and cultivated plants - found across kitchen gardens, fields and in households — that comprised the village 'plantscape'. Geographic information system (GIS) analyses of the locations of macroscopic remains of plants throughout the village reveal the cultural logic behind the placement of foodstuffs, such as beans (Phaseolus spp.), cacao (Theobroma cacao L.), chilli peppers (Capsicum annuum L.) and maize (Zea mays L.), particularly with regard to routine tasks related to everyday food production and consumption. Although few sites exhibit this level of preservation, the careful and intentional ordering of plants at Cerén has inspired, and will continue to serve as a useful analogue for, archaeologists to consider possibilities beyond taphonomy during excavation and analysis (such as is being done at Tikal and Aguateca).

Joya de Cerén was founded towards the end of the sixth century (during the Classic Maya period, AD 250-900) on the left bank of the Río Sucio, which drains the Zapotitan Valley (Sheets 2009; Figure 1). By the seventh century, this village of around 200 sedentary agriculturalists was similar to many other villages in the broad Zapotitan Valley, which also included larger settlements with elites, traders and marketplaces (Black 1983). 
The Cerén villagers cultivated the fertile, volcanic soils derived from the eruption of the Ilopango volcano approximately a century before (c. AD 539). They built their homes of wattle and daub and with grass-thatched roofs (Lentz et al. 1996a; Sheets 2002). Their agricultural fields produced surpluses sufficient for marketplace exchange for polychrome ceramics made in the Copán valley, obsidian tools, jade axes and pigments of haematite, limonite and cinnabar (Sheets 2000). The Cerén community was arranged into several households surrounding a large plaza. Each house consisted of a variety of structures for storing, sleeping, cooking and eating, along with trees, shrubs and kitchen gardens (Lentz \& Ramírez-Sosa 2002; Sheets \& Woodward 2002; Figure 1).

In the autumn of $c$. $\mathrm{AD} 660$, magma from the Loma Caldera vent, located only $600 \mathrm{~m}$ north-west of the village, came into contact with the water in the local river. This initiated an eruption that blasted a hot cloud of steam and fine volcanic ash onto the village. The seismic activity must have alerted the Cerén community to the imminent eruption (Miller 2002: 20). There was sufficient time to escape bodily harm, but not enough to take many possessions. As a result, plants, buildings and household objects were buried under $4-7 \mathrm{~m}$ of tephra (Miller 2002). This extraordinary coincidence of natural and cultural processes preserved the plantscapes of a Late Classic Maya village.

\section{Methodology}

\section{Plant collection methodology}

The plant evidence was collected by the Joya de Cerén archaeological research project using a variety of methods. Initially, carbonised plant remains were collected whenever they were encountered during excavation, and subsequently using a systematic water flotation strategy. Excavators quickly realised, however, that cavities in the ash just above the Late Classic (c. AD 550-830) activity surfaces represented plants that were intentionally planted or placed. Consequently, project team members employed plaster casting techniques similar to those used at the ancient Roman city of Pompeii to 'retrieve' these plants (Jashemski 1973). Upon encountering a hollow space, excavators investigated it with a fibre optic proctoscope to determine the species and the extent to which the space was occupied by the plant (Beaubien 2002: 173). The hollow space was then filled with dental plaster to form a 3D reproduction (Figure 2B). After the plaster hardened, each cast was excavated from the volcanic ash. While some plant remains were carbonised, others left only their impressions in the ash, or were wholly preserved.

\section{Identification of plant remains}

Plant remains were examined using a low-powered stereomicroscope $(7-70 \times$ magnification) at the University of Cincinnati Paleoethnobotany Laboratory. The casts were studied and curated in the Museo Nacional de Antropología David J. Guzmán in El Salvador. Only 450 of the thousands of recovered casts retained sufficient diagnostic characteristics to be identified. The GIS database used to model the locations of these plants comprises more than 600 items spanning 28 species.

(C) Antiquity Publications Ltd, 2017 
A

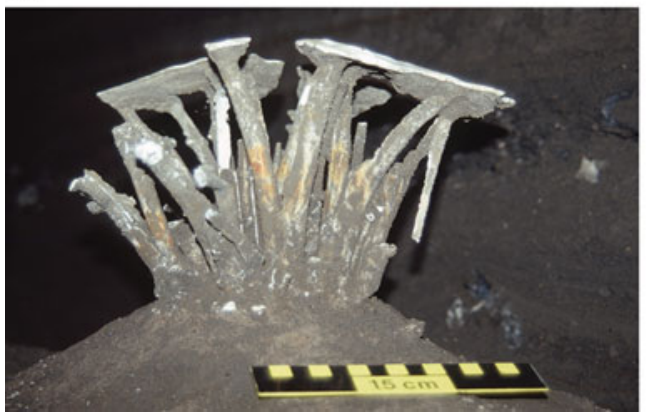

B

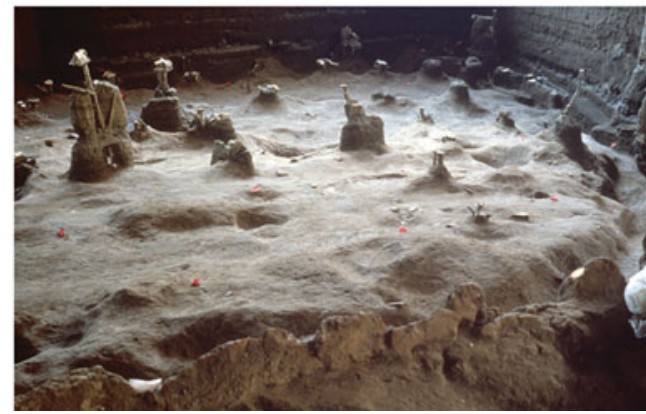

Figure 2. A) Photograph of malanga (Xanthosoma sagittifolium) plant casts from the Household 1 kitchen garden; B) view of the kitchen garden in the south-west corner of Household 1. Images by P. Sheets.

\section{GIS methodology}

Archaeological data and maps from the Joya de Cerén project were used to create the base layers for the geospatial database, using ESRI ArcGIS 10.2 software (Sheets \& McKee 1989, 1990; Sheets \& Kievit 1992; Sheets \& Simmons 1993; Sheets \& Brown 1996; Sheets 2002). A team from the University of California, Berkeley first created an arbitrary projection in Universal Transverse Mercator (UTM) using a local site datum. This provided the anchor for the base map (based on Sheets 2002: 2) upon which the structure maps produced by excavators were overlain. Each structure map, along with the fields and edges of excavation, was anchored to the base map using the correspondence of the original $1 \mathrm{~m} \times 1 \mathrm{~m}$ grid system.

Archaeological and architectural features, such as walls and surfaces, were operationalised as polygons, as were features such as gardens, fields, plant-drying patches and hearths. A $1 \mathrm{~m}$ buffer (not shown) was calculated for each structure to simulate the extent of the thatched roofing covering the ground outside the walls (except for Structures 2 and 12, which were $1.5 \mathrm{~m}$ and $0.3 \mathrm{~m}$ from wall to drip-line, respectively) (McKee 2002: 60). The GIS database contains attribute data for three artefact classes (ceramic, ground stone and chipped stone), two classes of organic remains (botanical and faunal), site drawings at multiple scales of resolution, and Google Earth imagery. The artefactual data are represented as points; the corresponding attribute data were derived from both published sources and project files. Thus, each class of artefact contains different attributes uniquely associated with it (e.g. 'Handle: Yes/No' for ceramics).

The archaeobotanical data used in the GIS visualisation of Cerén were derived from publicly available Field Specimen Lists (Ceren Web Resource n.d.) and published reports (Lentz et al. 1996b; Lentz \& Ramírez-Sosa 2002). Botanical remains were identified to genus and species where possible, and their life-status at the time of the eruption and the plant parts represented (e.g. seed, rind, stalk, etc.) were recorded. Plant-specific symbology was created for each taxon and plant part to facilitate the identification of the plants (Figure 3). The plant symbology indicates an individual plant's life-status-living, 
Plant Taxa

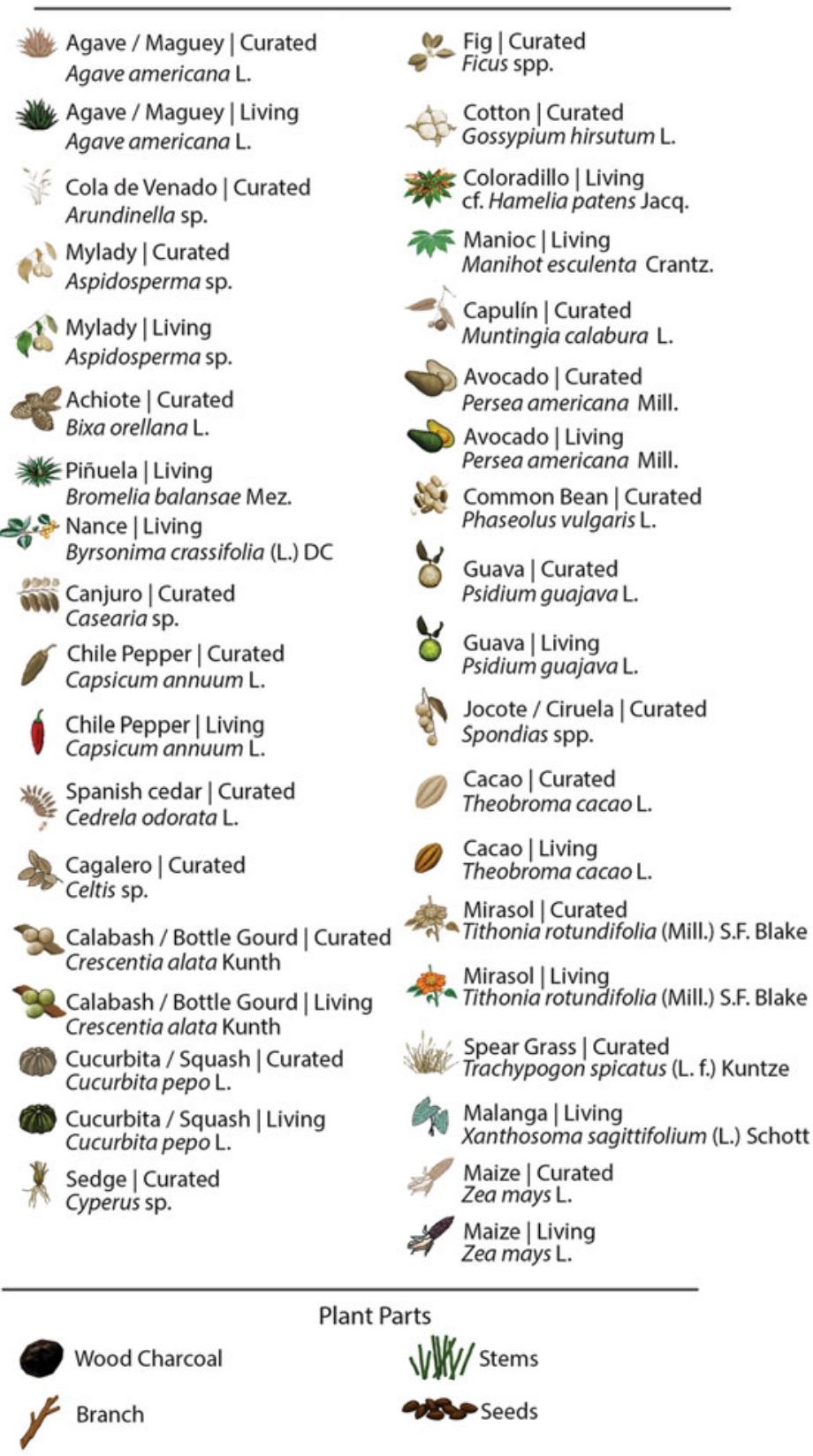

Figure 3. Key to plant symbols used in the figures. The term 'living' is used to indicate that the plant was alive at the time of the eruption. The term 'curated' is used to indicate that the plant was collected or dead at the time of the eruption.

(C) Antiquity Publications Ltd, 2017 
stored/curated or fallen - at the time of the eruption. The inclusion of this type of data provides a more precise representation of the Cerén village plantscapes.

\section{Botanical results}

\section{Plant presence at the settlement}

Maize was the most common living plant at Cerén, with 189 specimens recovered in excavations from the village alone-more than twice the number of any of the other identified species (e.g. Lentz \& Ramírez-Sosa 2002: 37), not counting the ancient fields adjacent to and south of the village. This abundance demonstrates that the inhabitants were growing maize in fields (known as milpas) next to their homes. Many of these maize plants were recovered using the plaster-cast process. Recent research to the south of the village has also recovered numerous mature manioc (Manihot esculenta Crantz) plant casts that grew alongside maize in these outer fields (Sheets et al. 2012). Although less common, manioc plants $(n=11)$ were also grown in the village. These were encountered primarily as stems and tuberous roots in kitchen gardens, most prominently in Household 1, adjacent to a milpa (Figure 4) between a store-room (Structure 6) and a kitchen (Structure 11; see Figure 5). This new evidence for extensive manioc cultivation, which is rarely preserved in the archaeological record, attests to the importance of manioc in Maya cuisine (Sheets et al. 2011). Guava (Psidium guajava L.) was the third most common plant encountered at Cerén $(n=89)$. The greater frequency of guava is linked to at least two living trees in Households 1 and 4, especially to the south of Structure 4 (Figure 6), where fruits were apparently dislodged from the trees during the eruption.

Another common plant was agave (Agave americana L., $\mathrm{n}=34$ ), which was identified from plant casts in a dense field on the southern side of Household 4 (Figure 6). Agave twine was found in numerous locations throughout the village, attesting to its frequent communal use. Four curated garden crops were also ubiquitous within these structures and patios: chilli peppers $(n=27)$, common beans $(n=16)$, cacao $(n=16)$, and calabash (Crescentia alata Kunth, $\mathrm{n}=13$ ) (Figure 7). These plants are thought to form part of the core of Classic Maya plant cultivation and cuisine, along with maize, manioc, guava, avocado (Persea americana Mill.) and squash (Cucurbita pepo L.) (Lentz 1999). As the spatial analyses below illustrate, these plants also tended to be found in close proximity to each other, attesting to their joint use in food preparation. Agave, cotton (Gossypium hirsutum L.) and calabash were used for the manufacture of cordage, cloth and other items, and as serving vessels, respectively (Lentz \& Ramírez-Sosa 2002).

A less common group of utilitarian plants at Cerén included mirasol (Tithonia rotundifolia [Mill.] S.F. Blake), a stout-stemmed member of the sunflower family. These plants were used for the construction of short-term barriers and fences found, for instance, to the north of Structure 4 (Figure 6). Other plants included Trachypogon spicatus (L.f.) Kuntze, a grass used for thatch on many of the village structures (Lentz et al. 1996a \& b), and the various woody plants found as charcoal used for cooking (e.g. Cedrela sp., Pinus oocarpa Schiede ex Schltdl., Ficus sp., etc.) (Figure 8B). 


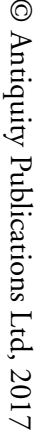

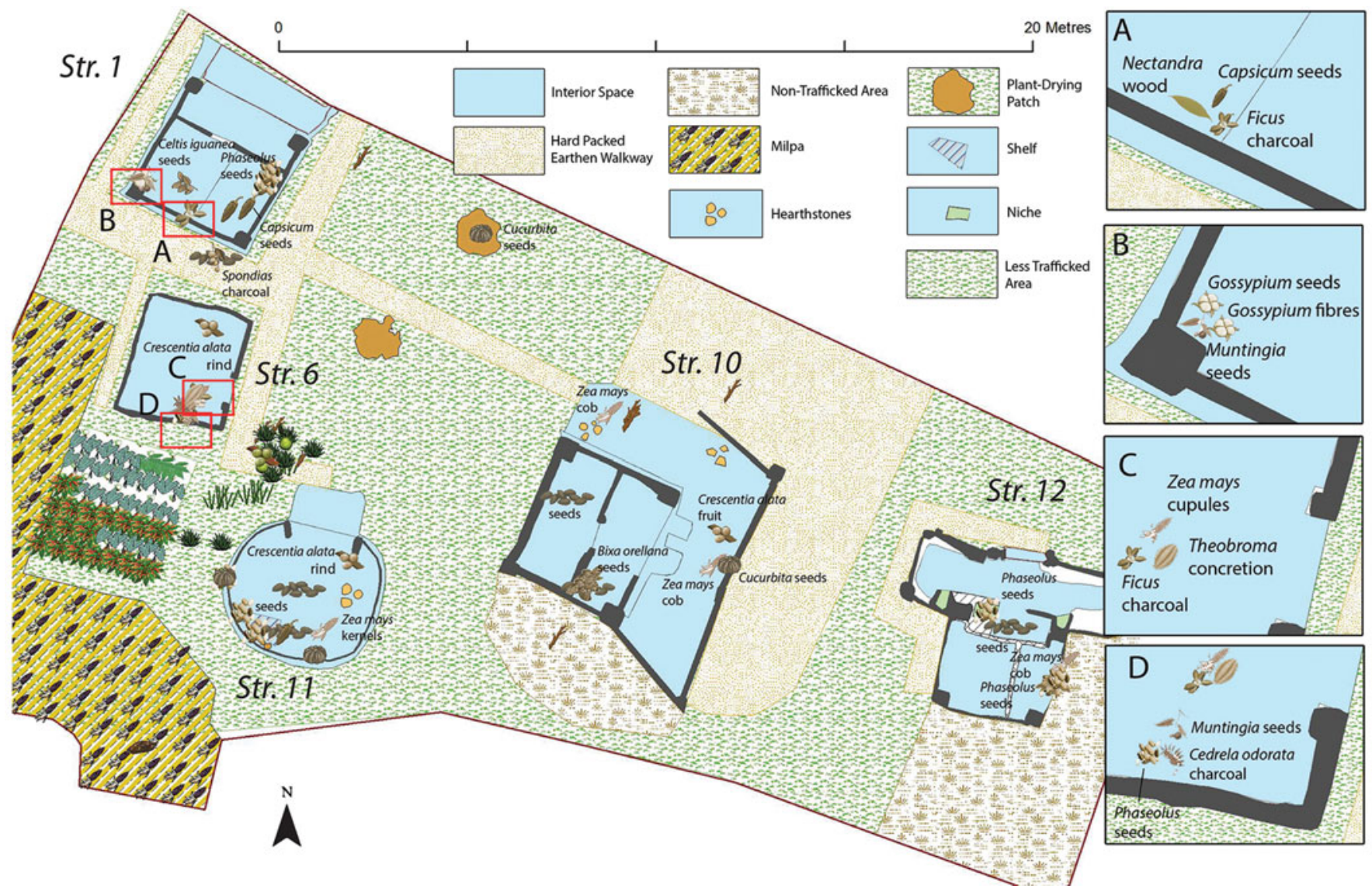

Figure 4. Map of Household 1 showing locations of the living and curated plants that were growing around the compound at the time of the eruption. Insets $A-D$ provide close-up views of plant clusters. 

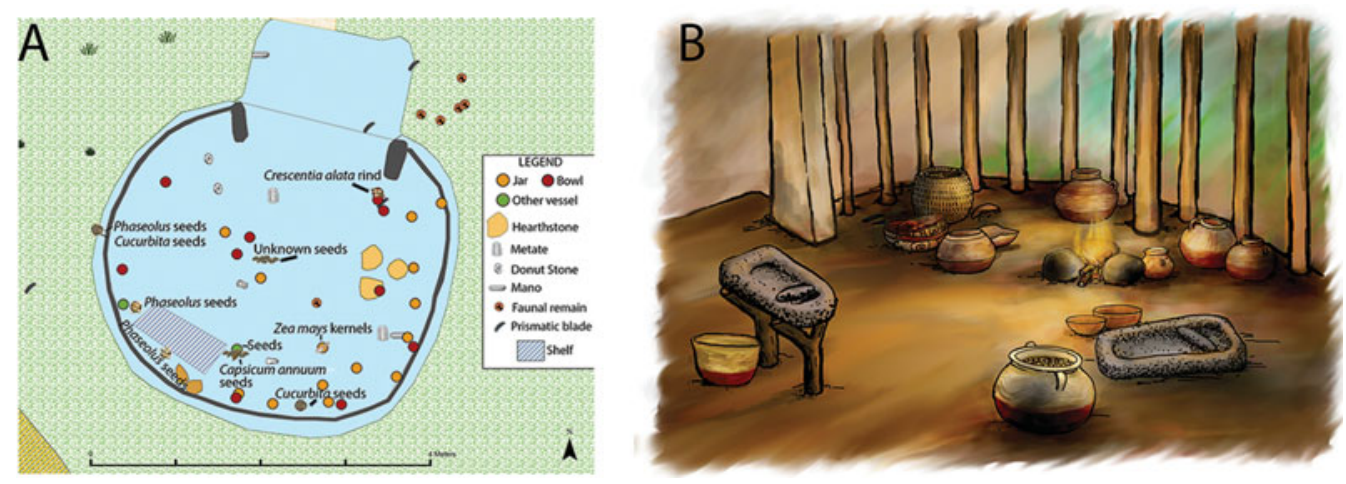

Figure 5. The kitchen (Structure 11) in Household 1 showing: A) the location of plants in association with other artefacts; B) a reconstruction of a kitchen workspace, by $A$. Harkey.

The Household 1 kitchen garden contained malanga (Xanthosoma sagittifolium L.), coloradillo (cf. Hamelia patens Jacq.) and one above-ground manioc tuber, which was probably harvested for immediate consumption (Lentz \& Ramírez-Sosa 2002). In addition to their location in gardens, many plants were stored and dried within structures. Maize, for example, was stored in a 'corn crib' in Structure 4 (Figure 8). Although the maize was husked, the kernels were still on the cob, suggesting that the residents retained both the cobs and the kernels.

\section{Household plant distributions - broader trends}

Several spatial analyses were conducted to ascertain whether plants were randomly distributed within structures (and if not, what the cultural logic was behind their placement), and whether different plants occurred in discrete associations. To achieve this, Average Nearest Neighbour and Near analyses were calculated. Average Nearest Neighbour compares the average distance between observed points against a hypothetical random Poisson distribution of those points within the same area (Fortin \& Dale 2005: 33-35). Near Analysis calculates the distances between an individual point (here, a plant specimen) and the next nearest point (another plant specimen). Near Analysis was calculated on the distances between individual plants within a distance of $0.5 \mathrm{~m}$ to focus on plants that might have been used in meal preparation and to exclude comparisons of the distances of plants between and outside structures. The distance of individual plant specimens from the walls of structures was also included.

The spatial distributions of the plants reveal that all households farmed both food and utilitarian crops, collected wild plants, and stored and cooked food within their households. Reinforcing initial observations (Lentz et al. 1996b: 259), the available data do not indicate that storage was exclusively limited to any one structure in any household. Curated plants were found in nearly every edifice, except in special-use structures, such as the sweat bath (Structure 9 in Figure 1), which was kept clean. Nonetheless, the distribution of plants within each household was non-random, and there are frequent spatial associations between important food plants, especially maize, beans, cacao and chilli, which were most often 


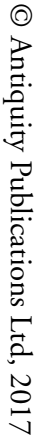

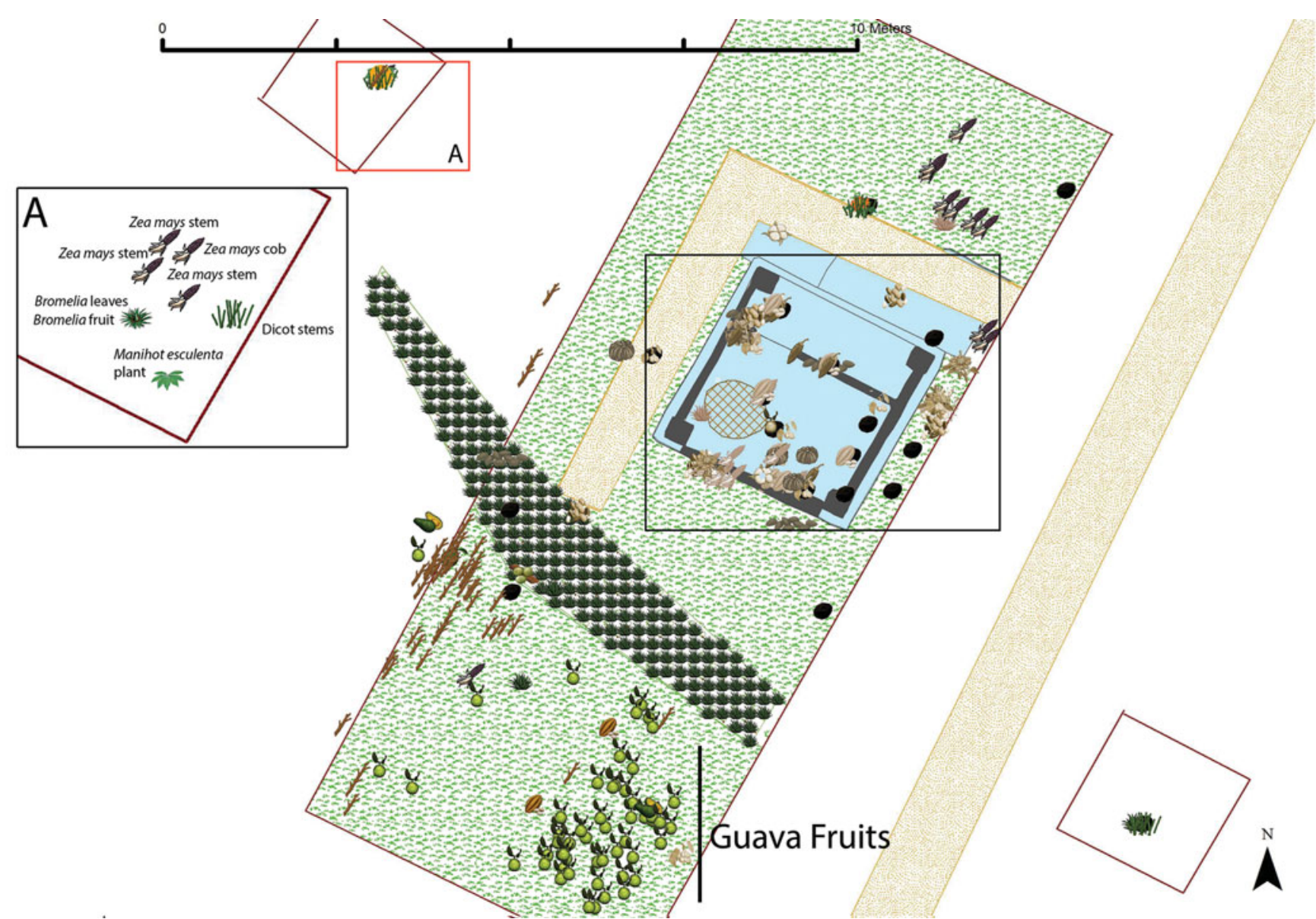

Figure 6. Map of Household 4, showing the location of all plant remains. Inset A provides a close-up view of plant clusters in a test pit to the east of the structure. The concentration of guava fruits (Psidium guajava) is highlighted due to possible deposition from tree fall. The box around Structure 4 is illustrated in Figure 8. 


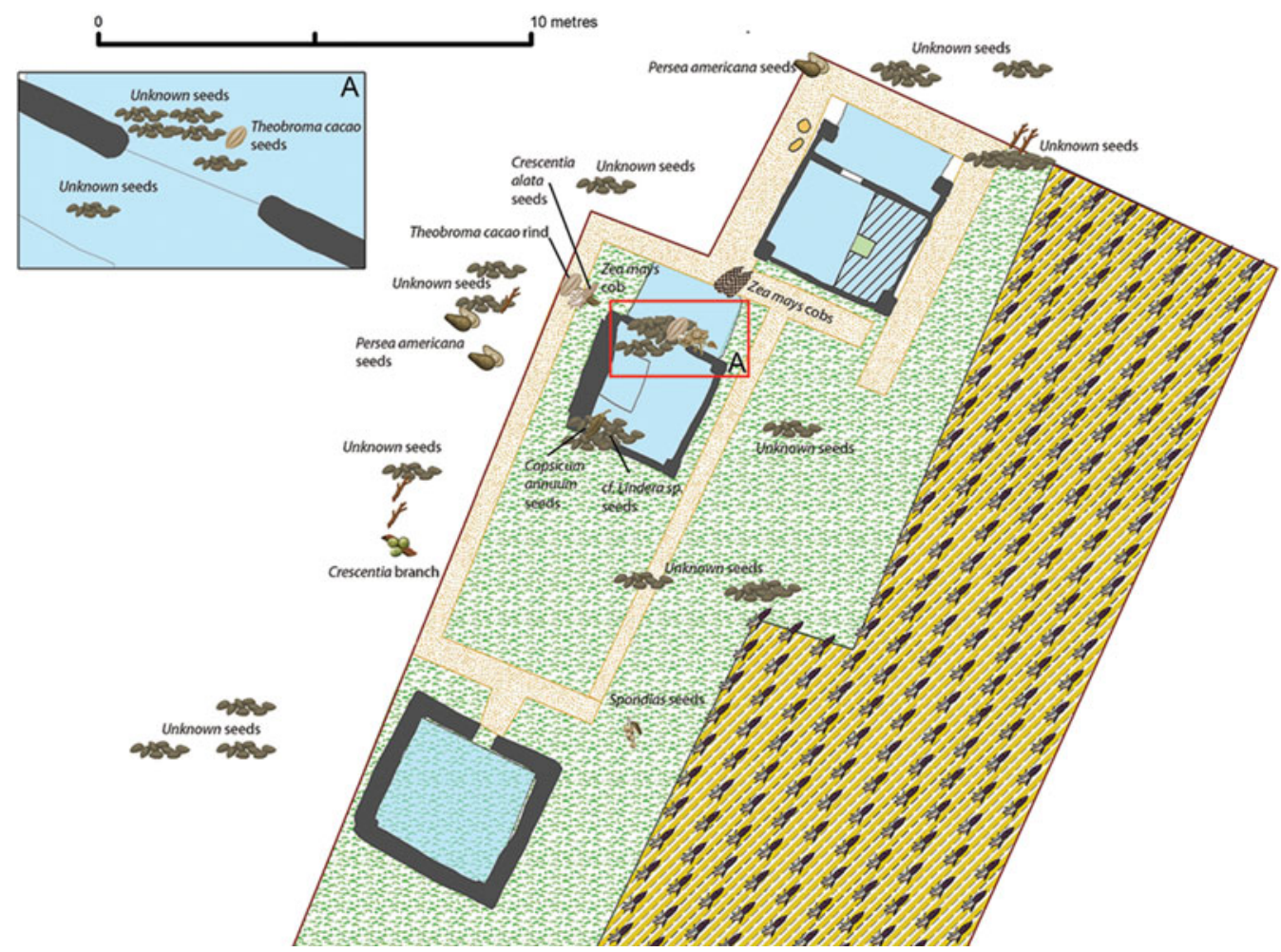

Figure 7. Map of Household 2 showing the location of all plant remains.

situated within $0.5 \mathrm{~m}$ of each other (Figure 9). One example of such repeated association is observed in the south-eastern corner of Structure 6 (Figure 4C), where maize cupules were found directly adjacent to a cacao 'clump', and in Structure 4 near the south wall (Figure 8E). The frequent spatial association of these plants, particularly in Structure 4, may be indicative of the raw ingredients of 'corn meal' (atole) flavoured by cacao and chilli. This supplements the evidence from containers (Lentz et al. 1996b: 251).

Plant remains were clustered in every structure in which they were present, and 75 per cent of the identified plant remains were within $0.38 \mathrm{~m}$ of structure walls (see online supplementary material Supplements $1 \& 2$ ), thus revealing the intentionality of plantstorage decisions. It may also more broadly inform Mesoamerican palaeoethnobotanical practice when designing sampling methodology for archaeological sites with standing architecture, but with less exceptional preservation. The exceptions to this trend are Structures 10 and 11, which contained one near-solitary cache of seeds among the plant remains farthest from structure walls. Ceramic vessels placed along structure walls played an important role in this 'clustered' plant storage, as exemplified by Structure 3 (Figure 8).

\section{Household plant distributions—specific trends}

Household 1 was the first group of structures that the project discovered and excavated. This group includes three residential buildings (1, 6 and 11) and two special-purpose buildings 


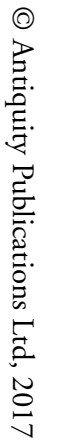

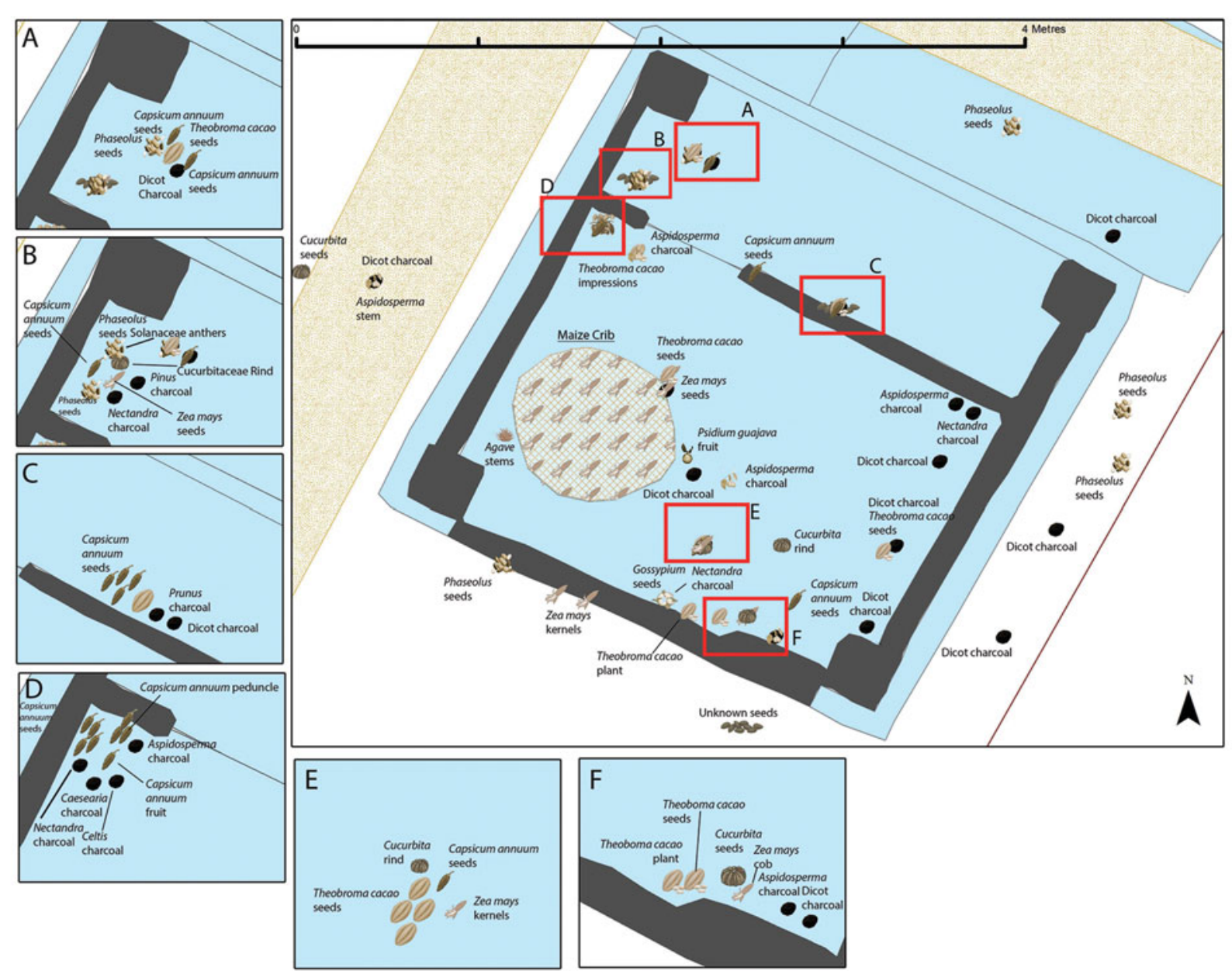

Figure 8. Map of Structure 4 showing curated plants recovered during excavation. Insets $A-F$ provide close-up views of plant clusters. 


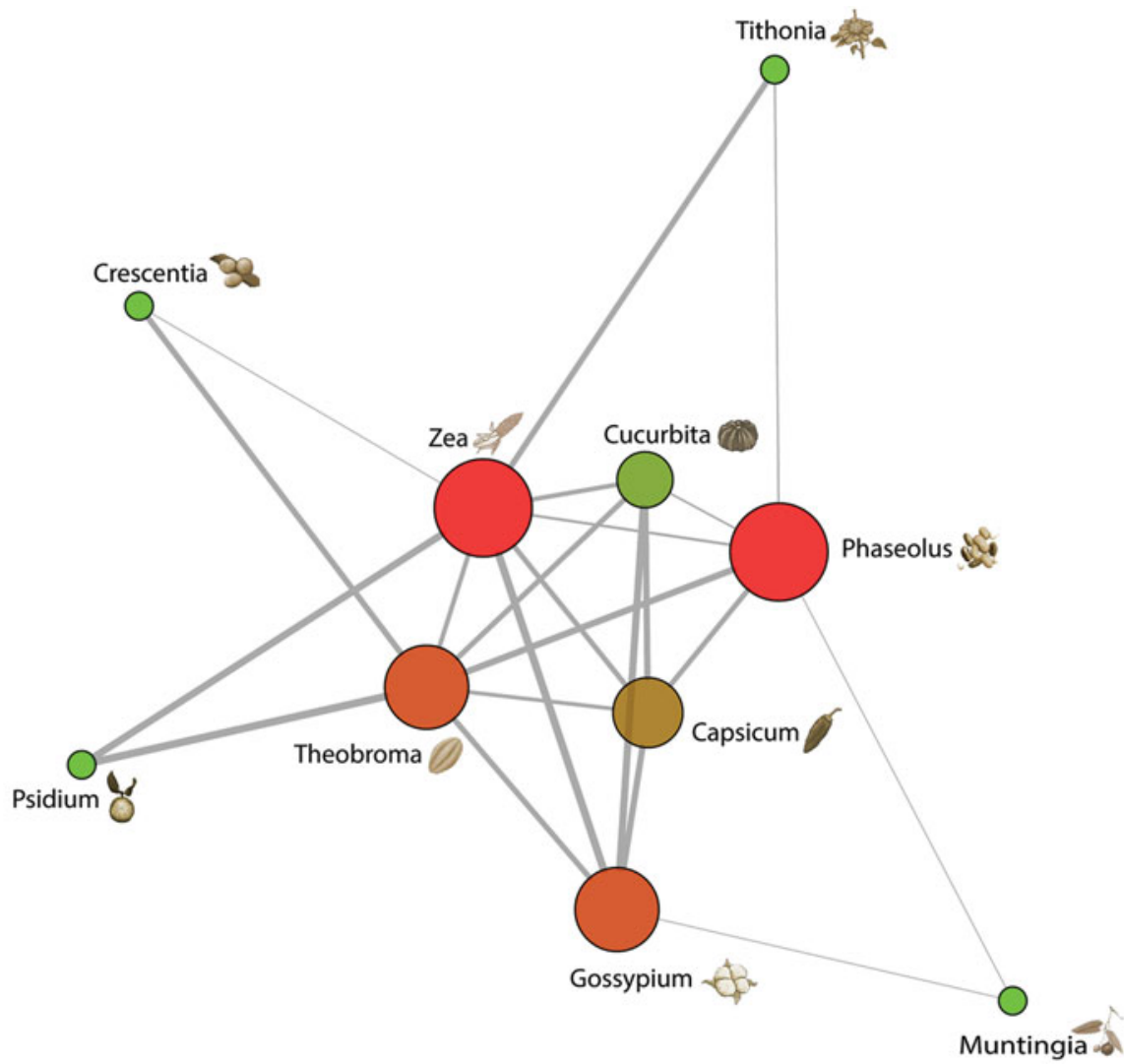

Figure 9. Network graph representing the spatial connections of major plant genera. Circle sizes and colours represent the number of plants within half a metre, anywhere across Cerén, of that particular plant (red, the maximum, represents seven; green, the minimum, represents two). Line thickness represents a greater average distance.

(10 and 12; Figure 4). The buildings are all oriented $30^{\circ}$ east of north and were constructed on raised and fire-treated earthen platforms (Brown \& Sheets 2000). With a mono-cropped maize milpa encircling the structures, a range of plant species was cultivated in the kitchen garden; rows of malanga and coloradillo, and manioc were probably continuously planted and harvested throughout the year (Figure 4). Preserved pathways illustrate how residents moved throughout the household space, often underneath the eaves of the thatched roofs, on informal paths between every structure and use-area. The open use-area between Structures 1, 6 and 10 contained two plant-processing locales, complete with metates and plant-drying racks. One of these stations (Figure 4) contained squash seeds, indicating that the squash had been recently cleaned and prepared, and perhaps even dried.

The stored plants in Household 1 can be illustrated through Structure 1, which contained foodstuffs such as chilli peppers, beans, capulín seeds (Muntingia calaburra L.), calagero (Celtis sp.) pits and cotton seeds located against the walls (Figure $4 \mathrm{~A} \& \mathrm{~B}$ ). Intriguingly, it is the only domestic structure that did not contain maize. The location of Spanish cedar charcoal (Cedrela odorata L.) probably indicates a fallen house beam, whereas the Nectandra 


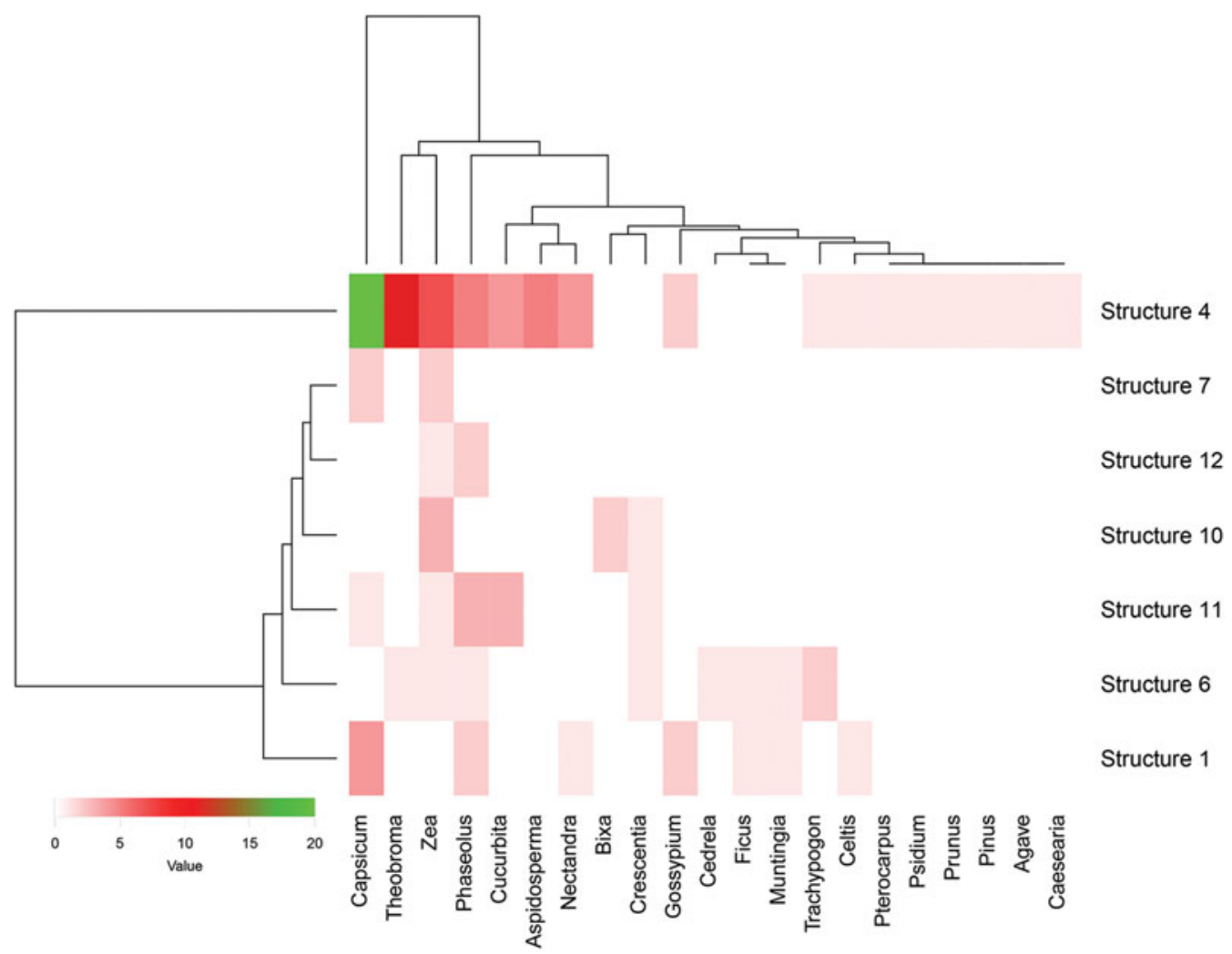

Figure 10. Hierarchical cluster analysis ('average' method) on the Manhattan distances of the number of plant remains found in each structure, represented in colour. The colour white is used to represent the absence of remains.

wood suggests fuel for small-scale cooking in a brazier. Food remains in nearby Structure 6 include maize and cacao, and the structure also contains Ficus charcoal, again possibly deriving from the material used to create the structure itself. Hierarchical cluster analysis of all of the recovered food plants and charcoal reveals that the structures nearest to each other (e.g. Structures 1 and 6) are more similar to each other in terms of the presence and absence of these plants, in particular maize, beans and chilli (Figure 10).

Structure 11 is the next most similar edifice to Structures 1 and 6 in terms of plant species present. It contained maize, beans, squash and chilli peppers in ceramic vessels, and the only in situ hearth, suggesting that more intensive indoor cooking was undertaken there. In contrast, the portable three-stone hearths found in other structures could have been used for less-involved cooking events. Measuring approximately $4 \mathrm{~m}$ across, the size of Structure 11 suggests that up to three cooks could have prepared a meal by grinding food in the centre of the structure, while mixing and cooking took place closer to the wall. Evidence for this process includes seeds in the centre of the structure, which represent some of the plant remains found farthest from the structure walls, at $1.4 \mathrm{~m}$. Moreover, numerous jars were located along the east and south walls of the structure. These contained maize kernels, probably soaking and awaiting processing (Lentz et al.

(C) Antiquity Publications Ltd, 2017 
1996b: 249), and squash seeds. Spaces immediately to the west of the hearth and north of the shelf that were free of 'clutter' indicate where the $\operatorname{cook}(s)$ would have sat to prepare meals (Figure 5). The meals prepared here were probably different than those in other structures. In 1 and 6, for example, there is evidence for snacking on capulín fruit and cacao, while a maize-based dish, such as pozole or tamales, was prepared in Structure 11 .

Unlike the other structures, 10 and 12 were defined as non-domestic religious buildings. Structure 10 was probably a ceremonial gathering space (Figure 4; Gerstle 1992, 1993; Brown \& Sheets 2000). Food preparation and cooking were undertaken outside and in public view, as demonstrated by the extant remains of two hearths, a metate and a maize cob; the sacred paraphernalia was confined to the innermost rooms. A jar full of annatto or achiote (Bixa orellana L.), used for food colouring or body paints, was also placed in the inner space, along with ornaments and headdresses. This indicates that the area was off limits to most people. Placed beside the eastern entry, meat-filled pots may suggest preparation for a communal feast, as indicated by the concentration of bowls and jars interspersed with a maize cob, squash seeds and calabash fruit. In contrast, Structure 12 appeared to be dedicated to divinatory practices. The recovery of beans and a variety of crystals (including quartz, orthoclase and plagioclase) in a niche in the north room and along the wall of the east room, corresponds to ethnographic research among the contemporary Maya, such as in Chimalteco, which reports the shamanic use of beans in ceremonies (Simmons \& Sheets 2002: 111).

Household 2 consists of two structures (2 and 7) that make up a domestic unit, with a special-purpose sauna (temezcal) to the south (Structure 9), which contained no plant remains (Figure 7). Two avocado trees grew within this household's immediate area (Figure 1), allowing household members to harvest and consume them regularly. This is apparent on the pathway along the western side of Structure 7, where avocado stones were probably discarded after consumption of the pulp. Cacao rinds and calabash seeds located just outside Structure 7, and probably in the eaves of the thatch roofing, suggest that food was being prepared near two living calabash plants and a single cacao tree. The two maize cobs found in front of Structure 7's entrance indicate that 'corn on the cob' had recently been consumed. Structure 2 is anomalous; as with Structure 1 , it features a shaded porch. No plants, however, were found inside this structure, with few plants found near the entrance. Perhaps, unlike the other households, the residents in Household 2 separated food preparation and consumption from sleeping, as a raised shelf is present within. While a maize milpa is located to the east of these structures, no mixed kitchen garden, or kitchen structure, has been uncovered to date.

Household 4 is the outlier in terms of plant engagement and group tasks within the Cerén community (Figures $6 \& 8$ ). Only one structure (Structure 4 ) has been uncovered thus far. Structure 4 features earthen columns and wattle-and-daub walls. It was built originally as a domicile, but was later remodelled into a storehouse. Maize was present in great quantities within, and its corn crib was full upon abandonment. Manioc, maize and chilli pepper grew to the west of the structure, suggesting that this outdoor area was a mixed milpa (Figure 6A). To the south, an agave field was cultivated (Gerstle \& Sheets 
2002). Farther south still, a high concentration of living, unharvested avocado fruit suggests that avocado trees grew there, along with a standing cacao tree. The people of Household 4 may have taken advantage of these fields in the immediate vicinity, which in part explains why this structure contains the greatest diversity of plant remains found throughout the site. Squash, beans, chilli pepper and cacao seeds were also identified throughout Structure 4, but particularly in small clusters against the walls. Such clustering suggests that they were stored in hanging net bags (Figure $8 \mathrm{~B}-\mathrm{F}$ ). Cotton seeds were ground on the metate, probably to extract oil for cooking. In comparison to the other excavated structures at Cerén, Structure 4 represents a more focused storage unit, rather than a living space or a cooking structure (Gerstle 1990).

\section{Discussion}

The arrangement of living and stored plants found throughout the village reveal a range of daily plant-related tasks in this Late Classic Maya community. Spatial analyses and the visual patterning of preserved plants by life phase show that most structures contained evidence of food or plant storage. Many plants were stored above ground, attached to the ceiling beams by twine or netted bags, or on the floor in vessels and in specially built features, such as the corn crib in Structure 4. There is currently no evidence for plant storage outside the structures. Trees also formed part of the architecture and plantscape, demarcating households and providing shade and food. Furthermore, while there is no evidence that fruiting trees were used for fuel, other Classic Maya sites, such as Tikal, do contain such evidence (Lentz et al. 2015). The people from the community of Cerén probably accessed the forests to gather wood for their hearths and braziers.

Gardens and fields, probably in an infield/outfield system, were a critical element of the Cerén plantscape. In the cleared land south of the village, ridged and furrowed fields of manioc, maize and beans undoubtedly provided a major portion of the calories for the community (Sheets \& Woodward 2002; Sheets et al. 2012). Manioc was grown in elevated beds in sloping locations, as its growth is inhibited by soils that are too moist, and could have been fertilised with night soil. In contrast, malanga, grown for its starchy corm, favours wetter soils and was planted alongside coloradillo in kitchen gardens, where it could be carefully tended and fertilised. Chilli peppers and other medicinal plants were also grown in and around the house compounds. To provide shade and fruit, economically productive trees, including guava, calabash, avocado, cacao, achiote, escoba, capulín, jocote and coyol were grown in and around the households. Wild plants used for construction, artefact manufacture and fuel were brought into the village from tropical upland forests, grasslands and wetlands.

The recurrence of plants in structures, located within close physical proximity to one another (particularly maize, beans, cacao and chilli), offers insights into the sets of ingredients that the Cerén community used in meal preparation. These plants were often found near the edges of walls. Plant remains recovered from samples taken from wall edges at other sites exhibiting less spectacular preservation are often considered the product of 'sweepings'; at Cerén, they are revealed to be an intentional method of organising the food plantscape for storage. Last but not least, the ability to observe the location of fields and (C) Antiquity Publications Ltd, 2017 
accurately depict the conditions under which crops were grown has contributed to a revision of our understanding of Late Classic Maya agricultural practices.

\section{Conclusions}

The Cerén community was intimately connected with their plants. The villagers tended and harvested them for food, medicinal and utilitarian purposes. They stored them inside their residences, hung them from ceilings, and stacked them within pots and bags in the corners of the structures. Although the villagers consumed the maize, beans and squash triad, even in ceremonial settings, it is clear now that they also regularly consumed manioc, malanga, chilli peppers and cacao. The village kitchen gardens, especially from Household 1, provide critical insights into the diverse range of plants that were intercropped and eaten.

This unique preservation setting provides visibility to what is often archaeologically invisible: namely, the difference between living and curated plants. Using GIS, it is possible to present visually a range of plantscapes in which the inhabitants lived, thus providing a unique glimpse into their work, storage and eating places, and their daily plant-tending chores. Beans, for example, are infrequently encountered in archaeological sites, especially in warm and humid environments. Cerén, however, contained abundant quantities of beans distributed throughout many structures and located both near and far from structure walls. The exact location of each of these specific plants at Cerén has provided direct evidence for analogous practices and tasks of plant-use and provisioning at other Late Classic Maya settlements. Recent research at the Late Classic Maya civic or ceremonial site of Aguateca, for example, relied on the Cerén findings to interpret the plant-use activities (Lentz et al. 2014). The Cerén land-use model was also invoked to explain how the Late Classic occupants of the major centre of Tikal managed their resources to sustain a large populace (Lentz et al. 2015). Although Tikal represents a complex polity with a large urban population and an extensive built environment, the same basic plant species were grown at Tikal, where the use of surrounding fields was intensified by reservoirs, irrigation canals and terraces. A GIS-based spatial distribution of plants at Cerén has facilitated the construction of a more nuanced, spatially oriented view of ancient Maya-period food practices. Furthermore, these findings contribute towards the understanding of the broader relationships of space, plant use and agriculture in the past.

\section{Acknowledgements}

Six grants from the Archaeology Program of the National Science Foundation to Payson Sheets and David Lentz (grant nos 1250629, 1115775, 0809217, 8819725, 9006482 and 9120716) supported this research. Permissions and assistance from many officials in the Salvadoran Directores de Patrimonio Cultural in the Secretaria de Cultura a la Presidencia are gratefully acknowledged. The GIS portion of this project was initiated in a graduate seminar at the University of California, Berkeley. Katherine Chiou, Rob Cuthrell, Alan Farahani, Anna Harkey, Shanti Morell-Hart, Annelise Morris, Peter Nelson and Jillian Swift organised and entered the Cerén data into an ArcGIS database, with the instruction and aid of Nicholas Tripcevich. We thank the two anonymous reviewers who provided critical and important feedback that improved the article. 


\section{Supplementary material}

To view supplementary material for this article, please visit https://doi.org/10.15184/aqy. 2017.119

\section{References}

Beaubien, H.F. 2002. The conservation program at Cerén, in P.D. Sheets (ed.) Before the volcano erupted: the ancient Cerén village in Central America: 169-77. Austin: University of Texas Press.

BLACK, K. 1983. The Zapotitan Valley archeological survey, in P.D. Sheets (ed.) Archeology and volcanism in Central America: the Zapotitan Valley of El Salvador: 62-97. Austin: University of Texas Press.

Brown, L. \& P.D. Sheets. 2000. Distinguishing domestic from ceremonial structures in southern Mesoamerica: suggestions from Cerén, El Salvador. Mayab 13: 11-21.

Ceren Web Resource. n.d. Field specimen lists. Available at: http://ceren.colorado.edu/Ceren_FS_ Lists/readme.html (accessed 15 May 2017).

Fortin, M.-J. \& M. DALE. 2005. Spatial analysis: a guide for ecologists. Cambridge: Cambridge University Press.

Gerstre, A.L. 1990. 1990 Operation 4 preliminary report, in P.D. Sheets \& B.R. McKee (ed.) 1990 investigations at Cerén: a preliminary report: 108-37. Boulder: Department of Anthropology, University of Colorado, Boulder.

- 1992. 1992 excavations at Structure 10, Joya de Cerén (Operation 8), in P.D. Sheets \& K.A. Kievit (ed.) 1992 investigations at the Cerén site, El Salvador: a preliminary report: 30-54. Boulder: Department of Anthropology, University of Colorado, Boulder.

- 1993. 1993 excavations at Structure 10, Joya de Cerén (Operation 8), in P.D. Sheets \& S.E. Simmons (ed.) Preliminary report of the Cerén Research Project, 1993 season: 46-90. Boulder: Department of Anthropology, University of Colorado, Boulder.

Gerstle, A.L. \& P.D. Sheets. 2002. Structure 4: a storehouse-workshop for household 4, in P.D. Sheets (ed.) Before the volcano erupted: the ancient Cerén village in Central America: 74-80. Austin: University of Texas Press.

JASHEMSKI, W.F. 1973. Large vineyard discovered in ancient Pompeii. Science 180: 821-30. https://doi.org/10.1126/science.180.4088.821

Lentz, D.L. 1999. Plant resources of the ancient Maya: the paleoethnobotanical evidence, in C.D. White (ed.) Reconstructing ancient Maya diets: 3-18. Salt Lake City: University of Utah Press.
Lentz, D.L. \& C. Ramírez-Sosa. 2002. Cerén plant resources: abundance and diversity, in P.D. Sheets (ed.) Before the volcano erupted: the ancient Cerén village in Central America: 32-44. Austin: University of Texas Press.

Lentz, D.L., M.L. Reyna de Aguilar, R. Villacorta \& H. Marini. 1996a. Trachypogon plumosus (Poaceae, Andropogoneae): ancient thatch and more from the Cerén site, El Salvador. Economic Botany 50: 108-14. https://doi.org/10.1007/BF02862115

Lentz, D.L., M.P. Beaudry-Corbett, M.L. Reyna de Aguilar \& L. Kaplan. 1996b. Foodstuffs, forests, fields, and shelter: a paleoethnobotanical analysis of vessel contents from the Cerén site, El Salvador. Latin American Antiquity 7: 247-62. https://doi.org/10.2307/971577

Lentz, D.L., B. Lane \& K. Thompson. 2014. Food, farming, and forest management at Aguateca, in T. Inomata \& D. Triadan (ed.) Life and politics at the royal court of Aguateca: artifacts, analytical data, and synthesis: 201-15. Salt Lake City: University of Utah Press.

Lentz, D.L., K. Magee, E. Weaver, J. Jones, K.B. Tankersley, A. Hood, G. Islebe, C. Ramos $\&$ N. Dunning. 2015. Agroforestry and agricultural practices of the ancient Maya at Tikal, in D. Lentz, N. Dunning \& V. Scarborough (ed.) Tikal: paleoecology of an ancient Maya city: 152-85. Cambridge: University of Cambridge Press. https://doi.org/10.1017/CBO9781139227209.009

McKeE, B.R. 2002. Household 2 at Cerén: the remains of an agrarian and craft-oriented corporate group, in P.D. Sheets (ed.) Before the volcano erupted: the ancient Cerén village in Central America: 58-71. Austin: University of Texas Press.

Miller, D. 2002. Volcanology, stratigraphy, and effects on structures, in P.D. Sheets (ed.) Before the volcano erupted: the ancient Cerén village in Central America: 11-23. Austin: University of Texas Press.

SheEts, P.D. 2000. Provisioning the Cerén household: the vertical economy, village economy and household economy in the southeastern Maya periphery. Ancient Mesoamerica 11: 217-30. https://doi.org/10.1017/S0956536100112039

- (ed.). 2002. Before the volcano erupted: the ancient Cerén village in Central America. Austin: University of Texas Press.

(C) Antiquity Publications Ltd, 2017 


\section{Identifying 'plantscapes' at the Classic Maya village of Joya de Cerén, El Salvador}

- 2009. Who were those Classic period immigrants into the Zapotitan Valley, El Salvador?, in B. Metz, C. McNeil \& K. Hull (ed.) The Ch'orti' Maya area: past and present: 61-77. Gainesville: University Press of Florida.

Sheets, P.D. \& L.A. Brown (ed.). 1996. Preliminary report of the Cerén Research Project, 1996 field season. Report prepared for the Secretaria de Cultura, El Salvador. Boulder: Department of Anthropology, University of Colorado, Boulder.

SheEts, P.D. \& K.A. Kievet (ed.). 1992. 1992 investigations at the Cerén site, El Salvador: a preliminary report. Boulder: Department of Anthropology, University of Colorado, Boulder.

Sheets, P.D. \& B.R. McKeE (ed). 1989. 1989 archaeological investigations at the Cerén site, El Salvador: a preliminary report. Boulder: Department of Anthropology, University of Colorado, Boulder.

- 1990. 1990 investigations at the Cerén site, El Salvador: a preliminary report. Boulder: Department of Anthropology, University of Colorado, Boulder.

Sheets, P.D. \& S.E. Simmons (ed.). 1993. Preliminary report of the Cerén Research Project, 1993 season. Report prepared for the Secretaria de Cultura, El Salvador. Boulder: Department of Anthropology, University of Colorado, Boulder.
SheEts, P.D. \& M. Woodward. 2002. Cultivating biodiversity: milpas, gardens, and the Classic period landscape, in P.D. Sheets (ed.) Before the volcano erupted: the ancient Cerén village in Central America: 184-91. Austin: University of Texas Press.

Sheets, P.D., C. Dixon, M. Guerra \& A. Blanford. 2011. Manioc cultivation at Cerén, El Salvador: occasional kitchen garden plant or staple crop? Ancient Mesoamerica 22: 1-11. https://doi.org/10.1017/S0956536111000034

Sheets, P.D., D.L. Lentz, D. Piperno, J. Jones, C. Dixon, G. Maloof \& A. Hood. 2012. Ancient manioc agriculture south of the Cerén village, El Salvador. Latin American Antiquity 23: 259-81. https://doi.org/10.7183/1045-6635.23.3.259

Simmons, S.E. \& P.D. Sheets (ed.). 2002. Divination at Cerén: the evidence from Structure 12, in P.D. Sheets (ed.) Before the volcano erupted: the ancient Cerén village in Central America: 104-14. Austin: University of Texas Press.

Received: 18 March 2016; Accepted: 5 October 2016; Revised: 19 March 2017 